\title{
Revisiting Reading: Exploring an intensive reading pedagogy in adult literacy
}

\author{
HELEN DE SILVA JOYCE, SUSAN HOOD and DAVID ROSE
}

\begin{abstract}
Applied linguistic research into genres of written communication has had a considerable impact in recent decades on the pedagogy of writing in all sectors of education in Australia, from early schooling to post-secondary and workplace contexts (eg. Christie and Martin 1997). Attending to the social purpose of language and modelling and deconstructing texts in preparation for supported writing has become a common feature of many programs, including those in the field of adult English as a Second Language (ESL) and adult literacy. However, effective engagement with model texts for writing is dependent on students being able to read those texts. While reading continues to be explicitly identified as a component of most adult literacy programs, there is evidence to suggest that less attention may be given to the deliberate supported development of reading skills (Burns and de Silva Joyce 2000, 2005). This paper reports on a project funded by the National Centre for Vocational Education Research (NCVER) in Australia. The study, Investigating the impact of intensive reading pedagogy in adult literacy, was designed to explore the relevance and the potential of an intensive, explicit reading pedagogy, Reading-to-Learn, in adult and community education (ACE) and TAFE colleges in metropolitan Sydney, teaching literacy in ESL and adult basic education (ABE) classes. The study was a partnership between practising teachers and researcher/teacher educators. It identified positive outcomes for students, with advances in reading abilities for many students well beyond those anticipated by teachers and students alike. Teachers also reported very positive outcomes for their own professional development. Importantly, the study also identified a number of system-level features that would need to be in place to support a broader adoption of the pedagogy.
\end{abstract}

\section{Introduction}

Genre-based literacy pedagogy, emerging from work in educational linguistics in Australia over the past two decades, has contributed to fundamental changes in literacy curricula locally (eg. Hasan and Williams 1996, Christie and Martin 1997) and internationally (eg. Johns 2002, 
Schleppegrell 2004). The pedagogy has been characterised by a strong focus on writing, and ongoing research and resource development in writing pedagogy continues to inform and support teachers of adult learners. However, some research suggests that it is time to invest more in understanding effective processes for teaching reading (Burns and de Silva Joyce 2000, 2005), and in particular the relationship between learning to read and learning to write (Barton, Tusting, Hodge, Appleby and Ivanič 2006, Brooks, Torgersen, Porthouse, Burton, Robinson, Wright and Watt 2004), and between learning to read and reading to learn (Rose 2004).

The role of reading as critical for the educational success of schoolaged learners is recognised in the recent Teaching Reading: Report and Recommendations from the National Enquiry into the Teaching of Literacy (Committee for the National Inquiry into the Teaching of Literacy 2005). It is equally crucial in the context of education for adult students of English language, literacy and basic education. Students who cannot access the key texts they need in order to learn, in whatever their educational sector or field of study, are at very serious risk of failure. In social contexts and workplace contexts adults who are limited in their ability to read are also limited in their ability to participate in their communities and workplaces.

The study reported here was designed as a deliberate and carefully planned and monitored intervention in the teaching of reading in adult and community education (ACE) and TAFE classes for adult ESL and adult basic education students. The study drew on an innovative approach to teaching reading referred to as Reading-to-Learn. It involved the professional development of six self-nominating teachers in relation to a specific set of pedagogical practices, ongoing monitoring of processes of implementation by the teachers and documentation of outcomes and issues. All teachers and students who participated in the study, and from whom data were collected, gave their willing informed consent to contribute to the study.

\section{'Reading-to-Learn' pedagogy}

The Reading-to-Learn pedagogy has been principally developed by $\mathrm{Dr}$ David Rose, who is a Research Fellow with the Faculty of Education at the University of Sydney. Developed initially in the teaching of academic reading and writing with Indigenous and other students in secondary schools (Rose 2004), and with Indigenous tertiary students at the University of Sydney (Rose, Lui-Chivizhe, McKnight and Smith 2004), it has since been adapted to other educational sectors and settings, including primary and secondary years of schooling and reading in tertiary academic contexts across Australia, Africa, China and Latin America (Culican 2006).

In brief, the pedagogy involves episodes of carefully designed structured and scaffolded intensive reading of short passages of key texts deliberately selected to be highly relevant to the student in terms of their 
educational goals and beyond what they can read independently. Students use notes made from the intensive reading process to jointly construct writing texts that are closely patterned on the reading. The approach is detailed in, for example, Rose et al. (2004) where the authors summarise it in these terms:

The scaffolding strategies for reading and writing are designed to focus students' attention on patterns of language and to recognise the meanings they express (...). These language patterns are very different from the language patterns that most of us use in everyday spoken discourse, and are often impenetrable to adults with limited or no experience of tertiary study. However, through the use of scaffolding strategies, a teacher can support learners to read and write far more complex texts than they normally could on their own (42).

The Reading-to-Learn approach incorporates principles of a languagebased theory of learning (Halliday 1993, Painter 1989, 2007) and a social constructivist perspective in terms of the concept of scaffolded interaction in learning (Vygotsky 1978, Van Lier 2004, Mercer 2002). As such, it is compatible with many current curricula descriptions and approaches in adult literacy. What is innovative in the Reading-to-Learn approach is the level of detailed and specific guidance in which teachers engage as they scaffold student achievement of tasks from the macro-level to the very micro-levels of texts. The approach introduces a more systematic, explicit and carefully scaffolded kind of intervention in the teaching of reading.

Evaluative studies of the Reading-to-Learn pedagogy in a number of sectors of education, particularly in schooling and in pre-academic contexts, have begun to generate a growing body of empirical data on implementation and outcomes (Culican 2006, Luke et al 2003). However, there had been no systematic exploration of how the pedagogy might function in the teaching of reading and writing in adult language, literacy and basic education programs. The specific nature of the learner profiles in this sector, the knowledge, expertise and training of teaching staff, the policy contexts and structures and the learning environments are all factors to be considered in any designed intervention in pedagogy. The most appropriate methodology for exploring the potential of the pedagogy was considered to be collaborative action research. Practising teachers self-nominated for the project and a selection from nominating teachers enabled the research to include a variety of program types, classroom contexts and teacher expertise. The teachers worked in partnership with researchers and teacher educators to investigate the processes and consequences of their own teaching in their own classrooms. This was done through cycles of designed interventions and ongoing data collection (eg. Burns 1999), followed by collaborative forums for problematising and solution-seeking. 


\section{Implementing the approach}

A key aspect of the approach is the careful selection by the teacher of genres and texts that are beyond the current reading ability of students, texts with which the students are unable to engage if unsupported. At a general level the teacher moves students through stages of detailed reading of those texts to joint rewriting and independent writing in a six-stage teaching cycle as illustrated in Figure 1 and described below. This general level of description of stages is explained in more detail later in the paper.

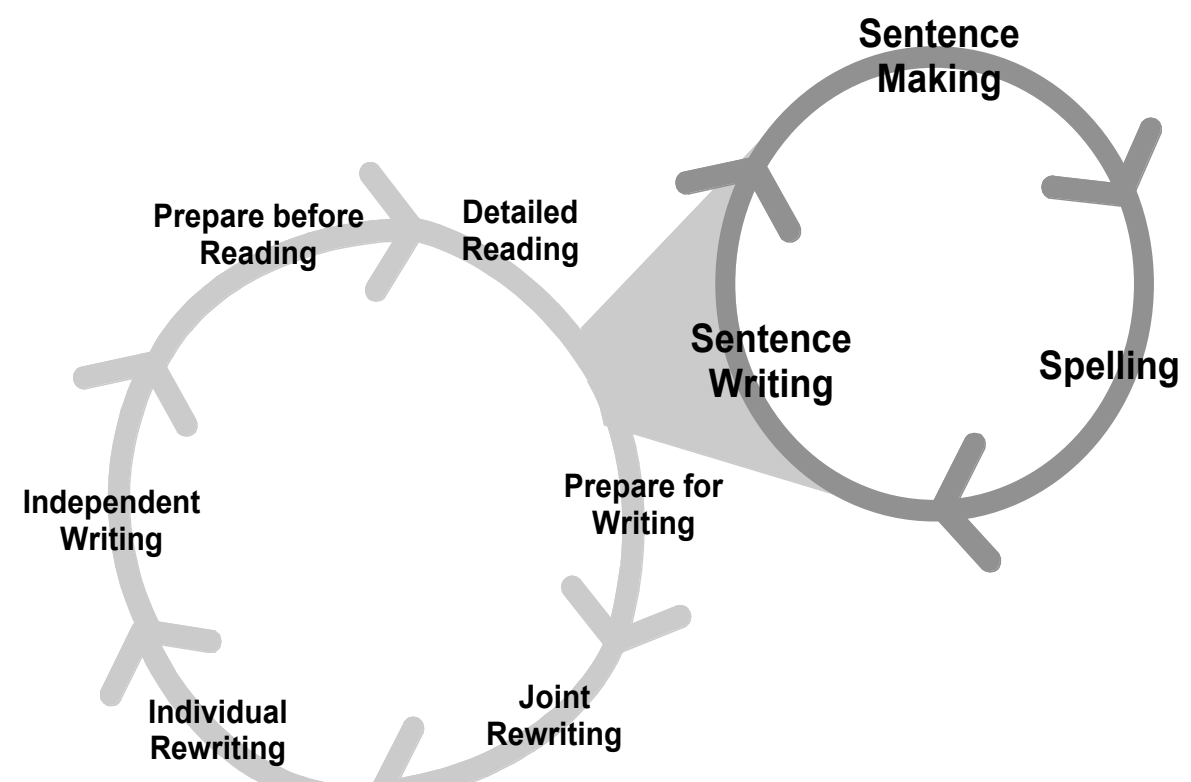

Figure 1: Reading-to-learn teaching cycle (Rose 2007, Book 1:26)

\section{Stage 1 Preparing before reading}

Students are oriented to the genre and field of the text and are prepared to understand the text in general terms. [The teacher gives a commonsense account of the content and sequence of that content, before reading the actual wordings to students]. 


\section{Stage 2 Detailed reading}

The teacher supports all students to read each sentence in a short passage, enabling students to read a passage with complete understanding and to understand how the author has constructed it. [The teacher gives a commonsense account of the first sentence, then reads it to students. Students are then carefully prepared to match meanings to wordings within that sentence. These connections are reinforced with elaboration moves].

\section{Stage 3 Preparing for writing}

Students plan exactly what they are going to write, based closely on the passage they have studied. In narrative texts, they will use the structure of the narrative as the scaffold. In factual texts they will use highlighted wordings as the scaffold.

\section{Stage 4 Joint rewriting}

The teacher supports the class to write a new text patterned on the reading text.

\section{Stage 5 Individual rewriting}

Students practise writing a new text using the same patterns as the reading and joint rewriting texts.

\section{Stage 6 Independent rewriting}

Students use what they have learnt from the preceding stages to write an independent text.

As can be seen in Figure 1, at each stage of the cycle students undertake activities that focus their attention on different levels of text structuring. As Rose explains in the professional development materials that are part of the training program (2007, Book 1, Part 1:4):

Reading and writing are hugely complex tasks that involve recognising and using patterns of language at three levels:

- $\quad$ At the level of the text, readers must recognise what a text is about and how it is organised, for example as sequences of events in stories, or as chunks of information in factual texts.

- At the level of the sentence, readers must recognise how words are arranged in phrases, and what each phrase means, such as who or what the sentence is about, what they are doing, where and when.

- At the level of the word, readers must recognise what each word means, and how letters are arranged into patterns that spell the word. 
The teacher engages in scaffolding moves that build connections between meaning and wording at each of the levels identified above.

Because of the carefully designed nature of the teaching intervention in Reading-to-Learn, and because it requires teachers to rethink and learn new ways of interacting with the language of written texts, in-service training of the teachers was an integral part of the project. The implementation in this study was centred on five workshops, conducted at intervals throughout the project. These workshops provided an introduction to the theoretical rationale, observations of videos of other teachers implementing the approach, opportunities for feedback and discussion of implementations and a review of the project upon completion. They also developed skills in identifying, analysing and preparing texts for teaching, lesson planning strategies, planning carefully sequenced interactions to scaffold students' engagement with texts, methods of data collection and assessment tools and strategies. The teachers were resourced with professional development booklets and a DVD of demonstration lessons. The three researcher/teacher educators worked with the teachers in delivering professional development workshops, coordinating data collection, observing classes and guiding teacher implementation of the pedagogy. As a first step the teachers were provided with detailed lesson plans but later in the project the teachers planned their own lessons with the support of the researchers. These lessons were either audio-recorded or video-recorded for reflection with the researchers and the other teachers in subsequent workshops. Data were collected from multiple sources during the project, and included recorded and transcribed group discussions, classroom observations, teaching practice records kept by teachers, student feedback, assessment of student reading and writing performances, and audio and video recording of lessons. These data and the teaching practice records were collaboratively reviewed and analysed by the teachers and researchers. The researchers analysed workshop discussions, samples of classroom discourse and other data for preparation of the final report and recommendations for future implementation of the pedagogy in adult literacy contexts.

\section{Outcomes}

The project was limited to six teachers who participated over a total of seven months and the classes involved covered a range of reading ability levels from beginner to intermediate. While limited in the number of teachers involved, the interaction with the research team meant that a considerable depth of data could be collected over more than one course during the project. 


\section{Outcomes for teachers}

One source of data was the teachers' ongoing records of their interventions and of observed consequences. The following extracts in Figure 2 are illustrative of this data. They identify a number of specific issues in relation to the teachers' evaluations of their own control of the pedagogy, the progressive development of confidence in the method, evaluations of student progress and responses and system issues that impact on implementation.

Teachers also collected student texts, produced in the different stages of the pedagogy.

Across the duration of the project teachers recognised changes in their practice and in their confidence as reading teachers. Initially they expressed a felt tension between finishing the sequence of tasks and a concern that their students were losing concentration. They also found it difficult to select appropriate well-constructed texts, to identify key phases of texts, to prepare texts for reading and manage exchanges that enabled students to connect meanings and wordings. However, as the teachers strengthened their professional knowledge in the workshops and developed a greater awareness of language and the implications of this knowledge for their teaching, these issues were no longer a concern. The teachers reported changing their practice in terms of developing clearer and more conscious planning processes.

\section{Outcomes for students}

Transcriptions of workshop discussions showed increasingly positive responses from students, and anecdotal incidences offered important insights. For example, one teacher reported spontaneous applause in her group when one student with a disability read a text aloud for the first time. Teacher feedback suggested that students responded positively to the more intensive and scaffolded approach to reading. They experienced success in reading in the successive cycles of Reading-to-Learn and became more confident in approaching reading tasks, as this comment from a beginnerlevel teacher shows.

Then I said 'okay, you want me to read this one again'? They said 'no, this time we want to have a go'. I said 'that's called "confidence". Let's do it'. And they did it. And when someone was reading, other students were helping. That's real nice ... That's something I want to see. So when they did it, I just stopped and I looked at them ... They managed to read the whole passage. So I mean they were quite comfortable with that one ... Now they can read much better than before, all three of them. 


\section{Figure 2: Extracts from one teacher's ongoing records of interventions and observed consequences}

\begin{tabular}{|c|c|}
\hline 1.8 & $\begin{array}{l}\text { During the detailed reading I realised I hadn't explained the sentences } \\
\text { sufficiently therefore I couldn't elicit the correct words to be highlighted. } \\
\text { At the end of the lesson one student said she felt she would learn to } \\
\text { read better with this method. Most students seemed to enjoy the lesson. } \\
\text { Everyone was involved. Some students remembered the exact words in } \\
\text { joint rewriting. }\end{array}$ \\
\hline 5.11 & $\begin{array}{l}\text { This was the first narrative text I have done with this class using this } \\
\text { method. The text turned out to be a good choice, with enough } \\
\text { complexity and new vocabulary to work well with the detailed reading } \\
\text { phase. The students really enjoyed the joint rewriting in a new context. } \\
\text { The original story was about a neighbour who came to a person's home } \\
\text { to complain about loud music. The students chose a classroom as the } \\
\text { new context, with an old woman from next door coming to the } \\
\text { classroom to complain about the rubbish being thrown into her yard by } \\
\text { the school children. I wish I had had time to complete the cycle, } \\
\text { however, I need to keep moving through other parts of the curriculum. } \\
\text { Next week's lesson I plan to complete the whole cycle through to } \\
\text { independent writing. }\end{array}$ \\
\hline 15.11 & $\begin{array}{l}\text { The students are now very comfortable with this method and are } \\
\text { enthusiastic to do each lesson. This time we did individual rewriting - } \\
\text { some students were very keen to have a go at this, but some were a bit } \\
\text { hesitant. However, everyone tried and they were still writing at 2.10pm } \\
\text { although our class should have finished at 2. Most of them took it home } \\
\text { and finished it for the next day. Each student wrote an interesting } \\
\text { variation on the ghost story and some included their own experiences. It } \\
\text { was a successful lesson. Although I had read and explained the whole } \\
\text { story at the beginning of the lesson one of the weakest students } \\
\text { commented that she understood the first } 3 \text { paragraphs really well } \\
\text { (which we had of course covered in the detailed reading), however she } \\
\text { found the other paragraphs really hard to understand. I realise it is not } \\
\text { possible to keep to the timings in the book (although I know these are } \\
\text { meant to be a guide). Explaining in common sense terms is not as easy } \\
\text { with ESL students as it would be with native or fluent speakers. }\end{array}$ \\
\hline
\end{tabular}


It was generally agreed that students improved their grasp of grammatical structures and became more interested in observing and talking about language, as this comment illustrates:

My students have learnt, have really appreciated unpacking nominal groups

but also we did some work repacking which wasn't what we did here but I

wrote the sentences up, four sentences and we repacked them into one sentence. A lot of work.

It was also reported that the use of electronic dictionaries by second language students greatly reduced over the duration of the project, with some students prepared to give them up altogether as they were provided with more effective means for understanding texts. Another unexpected reported outcome was a significant improvement in attendance patterns, attributed to the fact that students came to anticipate more rewards for attendance. The following comment by one of teachers shows that students were unwilling to miss out on classes:

My students and I are both sold on it, so we're sold. It's been very successful. In fact it's kept my students coming to class. You know um in that particular level in our TAFE college, it's only a small TAFE college, we have had historically a problem keeping people coming to class because of our population. We have older students who usually have family or work pressures, and increasingly work pressures in the government climate these days. Um so, starting off with say a small class of around 12, you're getting 12 enrolments and it gets whittled back and whittled back. But they've kept coming, primarily because they're enjoying the reading classes ... But they have gotten so much out of the reading because quite often, you know we've been focusing on media, they get stuck on the vocabulary or with the reference from outside, exophoric reference. So they've appreciated very much the classes and as I said they've kept coming.

Data collected during the project indicated improvements in student reading and writing skills. These improvements were, in many cases, unexpected and significantly beyond those predicted in curriculum outcomes. Student responses to the pedagogy were generally positive, with attendance patterns improving significantly and, in some classes, a noticeable increase in peer support. The pedagogy extended the grammatical resources of students and increased their enthusiasm for talking about the language of the texts they were reading and writing.

Teachers also kept records of student written feedback. In this instance of email reflection sent from an intermediate student to his teacher, the approval is very marked. 
Recently, $[\mathrm{X}]$ has been using a new teaching method to help us learn English in our class. It's a brand new experience for everybody. $X$ chooses one piece of a little bit harder essay to let us read. He asks us to speak aloud one by one even if we don't know some of words in the essay and he records each of our reading with a recorder.

The second part of his teaching is that he explains the whole essay, word by word, sentence by sentence, paragraph by paragraph. He emphasises on new words pronunciation and asks us to practise as well so that he can correct us gradually. He also analyses the structure of the sentences with grammar. He demands us to highlight every main word, phrase and clause when he explains it to us. And then, he asks us to read aloud again, sentence by sentence, and follow his reading.

The third part of his teaching is that he asks two of us to write a list of main words, phrases and clauses on blackboard we have highlighted in each paragraph and we help them to do the job. Then we work together with his help to make up the paragraph on the board without looking at the essay he gave us.

It doesn't matter whether the paragraph is the same as the essay's one. After we make our own paragraph up correctly he erases it and suggests us to rewrite it on our own paper by using the same method. He corrects our works later on when we have finished it. He might ask someone to write his/her paragraph on the board and we can examine it again together.

What a fantastic teaching method it is! It involves reading, reading aloud, pronunciation, vocabulary, spelling, comprehension, discussion, grammar as well as writing. I think it is very creative and every member of class gets involved in this procedure. Students can get the biggest benefit from this teaching method even if it is run a little bit more slowly than usual lessons.

$16^{\text {th }}$ May 2007

\section{Figure 3: Student email reflection}

Reading-to-Learn focuses on reading, and reading as foundational to writing, so data on student writing were also collected. Teachers reported widespread improvement in writing, which they attributed to students' improved language awareness and growing confidence in engaging with written texts. In particular teachers noted an increased interest in expanding their vocabulary and a growing sense of grammar on the part of the students, as this teacher explains.

And the third cycle I've done letter writing, I've used a really complex government written letter as a model and I've got some really good results in their writing and can see a really big improvement in the complex sentences and the grammar that they, even what I was really amazed with is that they've picked up articles, prepositions, um all those little things that 
normally we wouldn't expect them to pick up. So the third cycle I'm really

pleased, I've got some good results. I've been through, I did everything,

sentence-maker and note-taking.

Teachers also reported that students were able to write a wider range of story and factual genres, and were actively interested in considering textual organisation.

Intensive engagement in reading original texts included highlighting meanings/wordings and the students drew on these highlighted wordings to make notes on the board. Using alternative wordings to the notes on the board they then jointly reconstructed a version of the original text. From this the students proceeded to writing an independent construction in which they would drew on the organisational structuring and wordings from the jointly constructed text. The following student factual texts, in Figure 4, illustrate this process.

Text 1 Jointly constructed class factual text

Thomas Edison was an inventor, electrical engineer, businessman and industrialist. Born in Dublin, Ireland he was an ethnic Irish subject of the British Empire and later became an American citizen. Edison is famous for inventing electric light in the late $19^{\text {th }}$ century. Edison's work and inventions laid the foundation for the direct current battery power system (DC) including the invention of electric light bulbs which helped bring the age of electricity into the $20^{\text {th }}$ century.

Text 2 Sample A of independently constructed student factual text

Bruce Lee was born in San Francisco in 1942. When he was just a baby of 12 months old, he moved to Hong Kong with his father. At the age of five, he became a child actor and was know as Lee Xiao Long. He was famous throughout South-East Asia.

Figure 4: Student factual texts produced in joint construction and independent construction

\section{Comparative results}

One important aim of this study was to collect evidence of any impact (or otherwise) on students' literacy skills as a result of the interventions of the study. To this point we have noted sources of evidence in the form of teacher and student feedback on observed changes in literacy abilities, and indirect evidence in terms of behavioural and attitudinal shifts towards more positive engagement in learning. However, there was also a concern to identify more directly the changes in reading and writing practices for individual students. While a methodology of experimental design of pretest/intervention/post-test might suggest itself as an obvious choice in 
evidence gathering in a study such as this, there were several factors that restricted such a design. The timeframe for the project necessitated workshopping the methodology with teachers throughout the period of action research and data collection, rather than frontloading training. This meant that teachers were developing knowledge and skills that would inform effective initial assessment practices in reading across the duration of the project. Pre- intervention and post-intervention reading data were complicated in this regard. Part-time employment conditions, part-time provision, very varied teaching spaces and resources, irregular student attendance patterns, and students from multiple first language backgrounds were characteristics of the field. Rather than presenting factors to be controlled, these variables were seen as needing to be accommodated in the design and accounted for in the methods of data collection, reporting of findings and recommendations flowing from the study. An extended study would enable a second cycle of independent implementation in which teachers would attend more systematically to initial data collection of reading performances.

Nevertheless, it was considered important to provide evidence of a comparative nature beyond the important records of observation collected. Towards this end, samples of student independent writing were compared with benchmark performance samples for the relevant stage of the Certificates in Spoken and Written English (CSWE) (NSW AMES 2002). An example of such a comparison is provided in Figure 5 for a student studying at level II of the CSWE. In this case the genre that is compared is that of a recount.

Table 1 compares Text 3 and Text 4 in terms of 14 criteria at the levels of genre, register, discourse, grammar and graphic features. To produce a scaled comparison, each criterion is given a score between 0 and 3, with the CSWE II sample as a baseline with average scores of 1-2. The assessment resource illustrated in Table 1 has been developed in the Readingto-Learn program.

The analysis in Table 1 identifies how far student competence in story writing had progressed during their participation in Reading-to-Learn beyond the expected outcomes for their level. The writing of all students in this CSWE II class was within this range of 10 or more points above the expected average standard for that level. 
Text 3: Sample benchmark text from NSW Adult Migrant English Service (AMES) Assessment Booklet for CSWE II.

I visited Spain ten years ago. It is a beautiful country and I really liked it.

On the first day I went the museum. It was the biggest museum in the city. There were beautiful sculptures and the statues.

After that I went to lake near the city. I took an mony photos there, because it was a very nice view.

Then I went shopping and bought a small souvenirs for my friends.

On the last day I went to beach. I don't go swimming, because the weather was very cold, but I walked on the beach.

After ten days I returned home. It was a greatest holiday in my life and I enjoyed it.

Text 4: Sample of CSWE II student independent writing from project data

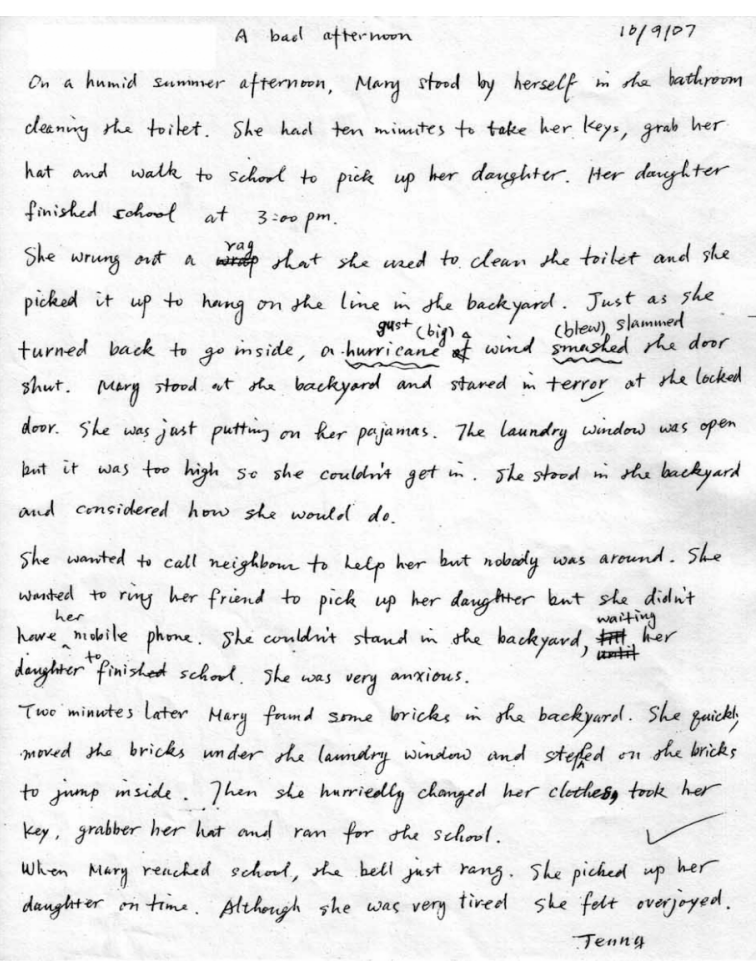

Figure 5: Comparison of GSWE II benchmark performance (Text 3) to text produced by student studying at GSWE II level in the study (Text 4$)$. 


\begin{tabular}{|c|c|c|c|c|}
\hline & Text 3 & & Text 4 & \\
\hline Purpose & simple personal recount & 2 & $\begin{array}{l}\text { successful narrative, } \\
\text { resolving complicating } \\
\text { events }\end{array}$ & 3 \\
\hline Staging & $\begin{array}{l}\text { Orientation, Record of } \\
\text { Events }\end{array}$ & 2 & $\begin{array}{l}\text { Orientation, Complication, } \\
\text { Resolution }\end{array}$ & 3 \\
\hline Field & $\begin{array}{l}\text { events and places in } \\
\text { personal travel } \\
\text { experience }\end{array}$ & 2 & imaginative, intricate plot & 3 \\
\hline Tenor & $\begin{array}{l}\text { some feelings and } \\
\text { appreciation of places }\end{array}$ & 1 & $\begin{array}{l}\text { engages with series of } \\
\text { problems and reactions }\end{array}$ & 3 \\
\hline Mode & $\begin{array}{l}\text { simple spoken English, } \\
\text { few written features }\end{array}$ & 2 & $\begin{array}{l}\text { more written features, } \\
\text { elaborations, variety of } \\
\text { sentence structures }\end{array}$ & 3 \\
\hline Phases & series of episodes in tour & 2 & $\begin{array}{l}\text { series of problems within } \\
\text { Complication- building } \\
\text { tension }\end{array}$ & 3 \\
\hline Lexis & $\begin{array}{l}\text { common lexis of places - } \\
\text { Spain, country, museum, } \\
\text { city, sculptures, statues, } \\
\text { lake, view }\end{array}$ & 2 & $\begin{array}{l}\text { rich lexis building field - } \\
\text { humid summer afternoon, } \\
\text { wrung out rag, turned back } \\
\text { to go inside... }\end{array}$ & 3 \\
\hline Conjunction & $\begin{array}{l}\text { simple succession - on } \\
\text { the first day, after that, } \\
\text { then, on the last day plus } \\
\text { cause because }\end{array}$ & 2 & $\begin{array}{l}\text { variety of time resources - } \\
\text { ten minutes, just as, two } \\
\text { minutes later, quickly, on } \\
\text { time }\end{array}$ & 3 \\
\hline Reference & $\begin{array}{l}\text { simple reference to self } \\
\text { and preceding things }-l \text {, } \\
\text { it }\end{array}$ & 1 & $\begin{array}{l}\text { variety of reference to } \\
\text { people and things }\end{array}$ & 2 \\
\hline Appraisal & $\begin{array}{l}\text { common feelings and } \\
\text { appreciation - beautiful, } \\
\text { liked, biggest, very nice, } \\
\text { greatest, }\end{array}$ & 1 & $\begin{array}{l}\text { appraisal used to build } \\
\text { problems and reactions - } \\
\text { stared in terror, very } \\
\text { anxious, hurriedly, overjoyed }\end{array}$ & 2 \\
\hline Grammar & $\begin{array}{l}\text { problems with number } \\
\text { and tense - an mony } \\
\text { photos, small souvenirs, I } \\
\text { don't go swimming }\end{array}$ & 2 & $\begin{array}{l}\text { few problems, variety of } \\
\text { sentence structures used } \\
\text { creatively }\end{array}$ & 3 \\
\hline Spelling & one error, mony & 2 & $\begin{array}{l}\text { accurate spelling of } \\
\text { infrequent words }\end{array}$ & 3 \\
\hline Punctuation & $\begin{array}{l}\text { accurate sentence } \\
\text { punctuation }\end{array}$ & 2 & $\begin{array}{l}\text { accurate sentence } \\
\text { punctuation }\end{array}$ & 2 \\
\hline Presentation & $\begin{array}{l}\text { uses paragraphs for each } \\
\text { episode }\end{array}$ & 2 & $\begin{array}{l}\text { uses paragraphs for stages, } \\
\text { title, fair handwriting }\end{array}$ & 2 \\
\hline Total & & 25 & & 38 \\
\hline
\end{tabular}

Table 1: Comparative analysis of student story text performances 


\section{Summary reflections on impact and implications for methodology in adult literacy}

At the end of the project, the teachers and researchers reviewed a range of issues that the project had highlighted about the teaching of reading to students in adult English language, literacy and basic education classes. These included reflections on past practices and the challenges that participation on the project had presented, as well as recommendations for further broader implementation.

One challenge that emerged early and persisted to some extent was the issue of choosing texts of sufficient challenge to students to enable learning to take place. Initial reading assessments of students were undertaken by teachers using miscue analysis techniques that involved the students reading aloud and the teacher recording 'miscues' of different kinds on a copy of the text. A review of the initial assessment data revealed a tendency to select unchallenging texts for the students to read, reflecting an underestimation of their reading abilities or a reluctance to challenge. If unchallenging texts are chosen for teaching reading, this can result in students not being sufficiently stretched to indicate directions for intervention and development. The pace for teaching is therefore unclear. A reluctance to introduce challenging texts into the classroom can also contribute to a prevalence of reading tasks that essentially test rather than teach reading, as is the case with the many kinds of read-and-answerquestions activities. Once the teachers in this study acquired more familiarity with the pedagogy and more knowledge about the language of texts they were prepared to choose texts that presented a more difficult challenge for students.

In terms of overall impact of the project and future potentials, the following emerged as key issues:

- $\quad$ The Reading-to-Learn pedagogy had positive impacts in the adult literacy classrooms involved in the project. These included improvement in student achievements in reading and writing and in attitudes to learning as evidenced, for example, in active participation and attendance patterns. For the teachers there was growth in professional knowledge, especially knowledge about language, with flow-on impacts in systematic and principled planning and teaching.

- Implementing the Reading-to-Learn pedagogy required some intensive retraining of teachers and periodic intervention by experts over an extended period. The means by which the pedagogy was introduced to teachers in this study, through professional development workshops interwoven with periods of implementation, reflection and classroom observation, proved effective. 
- Such an introduction to the Reading-to-Learn approach on a broader scale in the adult literacy sector would require commitment of time and funds and ongoing institutional support. For this reason it is predicted that the Reading-to-Learn pedagogy would be most easily introduced within organisations that already have strong literacy strategies and supportive senior staff and program managers.

Ongoing institutional support would be needed so that teachers could be released for workshops, teamwork would be facilitated and teachers could work consistently on the pedagogy with groups of learners over more than one course. Teachers would need to volunteer and commit to training, implementation and evaluation. The detailed training resources that support the precise approach of the pedagogy would need to be revised for adult contexts and linked to the curricula used in adult language and literacy contexts.

- There are a number of aspects of programming and teaching which characterise adult literacy contexts and which need to be accommodated in the design of further implementation. These include part-time employment conditions, part-time provision, very varied teaching spaces and resources, irregular attendance patterns, disparate student groups and students from multiple first language backgrounds. It was also felt that this difficult teaching context also provided an imperative for more carefully planned approaches if students are to develop sufficient reading and writing skills for social and work contexts during the time available.

- To deal with the complexities of adult literacy teaching contexts, teachers adapt and make on-the-go decisions about what to do next in classrooms. However, to maintain the integrity of the Reading-toLearn pedagogy teachers need to appreciate the rationale for the very precise steps of the pedagogy. The careful attention to wording and meaning relations within texts required teachers to unlearn some common practices.

To conclude, we argue that in the current climate, where there is an increasing pressure on adult language and literacy providers to prepare students for the reading and writing requirements of the workplace, it is vital that more explicit and carefully planned methodologies are adopted. The results of the NCVER project outlined in this paper indicate that the Reading-to-Learn pedagogy can greatly assist students to develop sufficient reading and writing skills for social and work contexts during the short time they have available to access language and literacy programs.

\section{Acknowledgements}

The authors would like to take this opportunity to thank the teachers who took part in the National Centre for Vocational Education and 
Research (NCVER) project during 2007 for the insights into adult literacy they provided and their dedication to improving classroom practices for their students. The full report on the project, as well as a Good Practice Guide is available from NCVER at www.ncver.edu.au/publications/1714.html.

\section{References}

Barton, D, Tusting, K, Hodge, Y, Appleby R, and Ivanič, R (2006) Linking Learning and Everyday Life: A social perspective on adult language, literacy and numeracy class, National Research and Development Centre for Adult Literacy and Numeracy, London.

Brooks, G, Torgersen, C, Porthouse, J, Burton, M, Robinson, A, Wright, K and Watt, I (2004) Adult Literacy and Numeracy Interventions and Outcomes: A review of controlled trials, National Research and Development Centre for Adult Literacy and Numeracy, London.

Burns, A (1999) Collaborative Action Research for English Language Teachers, Cambridge University Press, Cambridge.

Burns, A and de Silva Joyce, H (eds) (2000) Teachers' Voices 5: A new look at reading practices, National Centre for English Language Teaching and Research, Sydney.

Burns, A and de Silva Joyce, H (eds) (2005) Teachers' Voices 8: Explicitly supporting reading and writing in the classroom National Centre for English Language Teaching and Research, Sydney.

Christie, F and Martin, J R (1997) Genres and Institutions: Social processes in the workplace and school, Cassell, London.

Committee for the National Inquiry into the Teaching of Literacy (2005) Teaching Reading: Report and Recommendations from the National Enquiry into the Teaching of Literacy, Department of Education, Employment and Workplace Relations, Canberra.

Gulican, S (2006) Learning to Read: Reading to learn, a Middle Years literacy intervention research project, Final Report 2003-4, Catholic Education Office Melbourne, http://www.cecv.melb.catholic.edu.au/Research and Seminar Papers, www.readingtolearn.com.au

Halliday, M A K (1993) Towards a Language-Based Theory of Learning, Linguistics and Education 5, pp 93-116.

Hasan, R and Williams, G (eds) (1996) Literacy in Society, Longmans, London.

Johns, A (ed) (2002) Genre in the Classroom: Multiple Perspectives, Lawrence Earlbaum, Mahwah NJ,

Luke, A, Elkins, J, Weir, R L, Carrington, V, Dole, S, Pendergast, D, Kapitzke, C, van Kraayenoord, C, Moni, K, McIntosh, A, Mayer, D, Bahr, M, Hunter, L, Chadbourne, R, Bean, T, Alvermann, D, and Stevens, L (2003) Beyond the Middle: A Report about literacy and numeracy development of target group students in the middle years of schooling, Vol 1, Commonwealth Department of Education Science \& Training, Queensland. 
McRae, D, Ainsworth, G, Cumming, J, Hughes, P, Mackay, T, Price, K, Rowland, M, Warhurst, J, Woods, D and Zbar, V (2000) What has Worked, and Will Again: The IESIP Strategic Results Projects, Australian Curriculum Studies Association, Canberra, pp 24-26 www.acsa.edu.au, www.readingtolearn.com.au

Mercer, N (2002) Developing Dialogues, in Wells, G and Claxton, G (eds) Learning for life in the 21st century, Blackwell, Oxford, pp 141-153.

NSW Adult Migrant Education Service (2002) Certificates in Spoken and Written English (CSWE), NSW Adult Migrant English Service, Sydney.

Painter, C (1989) Learning the Mother Tongue, Oxford University Press, Oxford.

Painter, C (2007) Language and Learning in Early Childhood, in Christie, F and Martin, J R (eds) Language, Knowledge and Pedagogy, Continuum, London.

Rose, D (2004) Sequencing and Pacing in the Hidden Curriculum: How indigenous children are left out of the chain, in Muller, J, Morais, A and Davies, B (eds) Reading Bernstein, Researching Bernstein, Routledge Falmer, London, www.readingtolearn.com.au

Rose, D (2007) Reading-to-Learn Professional Development Materials Book 1, Part 1, http://www.readingtolearn.com.au/, pp 32-71

Rose, D, Lui-Chivizhe, L, McKnight, A and Smith, A (2004) Scaffolding Academic Reading and Writing at the Koori Centre, in Australian Fournal of Indigenous Education, 30th Anniversary Edition, pp 141-153, www.atsis.uq.edu.au/ajie, www.readingtolearn.com.au

Rose, D, Rose, M, Farrington, S and Page, S (2008) Scaffolding Literacy for Indigenous Health Sciences Students, in Fournal of English for Academic Purposes, pp 165-179, www.readingtolearn.com.au

Schleppegrell, M (2004) The Language of Schooling: A functional linguistic perspective, Lawrence Erlbaum Associates, Mahwah, New Jersey.

Van Lier, L (2004) The Ecology and Semiotics of Language Learning: A socio-cultural approach, Kluwer Academic Publishers, Amsterdam.

Vygotsky, L S (1978) Mind and Society: The development of higher psychological processes, Harvard University Press, Cambridge Massachussetts. 